\title{
COMPREHENSIVE DIAGNOSTICS OF RISK ASSESSMENT FOR SUSTAINABLE DEVELOPMENT OF RURAL AREAS
}

\author{
Tatjana Tambovceva ${ }^{1}$, Maria Tereshina ${ }^{2}$ \\ ${ }^{1}$ Riga Technical University, Latvia; ${ }^{2}$ Kuban State University, Russia \\ tatjana.tambovceva@rtu.lv, mwstepanova@mail.ru
}

\begin{abstract}
The scientific problem of this research is to overcome the lack of knowledge about the complex multicomponent risks of sustainable development of rural areas of different origins, and the mechanisms of their levelling. The purpose of the study is to develop methods for diagnosing risks to identify links between the current state of resources for sustainable development of rural areas and the tasks planned to be achieved. The study offers an analytical toolkit for comparative studies of rural development practices and also opens up broad empirical opportunities for cross-regional comparisons, typology of rural areas according to the level of sustainable development risks based on the proposed methodology and the development of appropriate management measures. The research methodology is interdisciplinary. The main methodological construction is the spatial approach, which involves the study of the spatio-temporal dynamics of various phenomena of social and economic life. The paradigm of sustainable development and its new hybrid models (green and blue economy, low-carbon, circular economy) are used as a framework for identifying the main groups of risks for sustainable development of rural areas, taking into account social, economic and environmental components. The developed methodology for assessing the risks of sustainable development of rural areas consists of constructing estimates of private risks using normalized values of the initial indicators and, on that basis, determining the consolidated risk. For the managerial and economic practice, the relevance of this study is due to the urgent need to find effective models for the development of rural areas, which, despite the variety of institutional practices, as well as consistent design of rural development in different countries, do not have sustainable socio-economic results.
\end{abstract}

Keywords: rural areas; sustainable development; risks; risk assessment.

\section{Introduction}

Rural areas, which are the most important subsystem of society, are characterized by specific goals, objectives and principles of development. Analysis and diagnostics of processes, permanently occurring in rural areas and caused by rapid changes in external and internal factors of influence, is complicated by the heterogeneity of rural areas in terms of the availability of economic, demographic, social, natural and infrastructural resources, cultural landscape, specialization or the chosen development model, as well as risks determined by the listed conditions.

Rural development is an uneven process. Currently, two areas of research can be distinguished: sustainable development with a dominant ecological component and various multifactor models. The first direction is developed mainly by ecologists focused on preserving the natural resource potential of rural areas, primarily focused on ecologists who analyse the resource potential as a basis for preserving the biosphere [1] or economists who analyse promising models of a "green" economy (e.g., ecotourism). Researchers of the second direction identify several factors of sustainability, Merenkova [2] classifies territorial factors of sustainable development (external and internal), as well as factors of sustainability associated with the economic, social, institutional and environmental spheres or direct and indirect the nature of their influence. Lemetti analyses the factors of the macroenvironment (cyclical factors), which include geopolitical and geoeconomic, climatic, historical and cultural, as well as microenvironmental factors - internal factors [3]. It should be noted that the complexity of the research object to date does not allow developing a unified vision of the essence of sustainable development of rural areas. This fundamental problem is reflected in the scientific research discourse, as well as in most political program documents of various countries.

For example, in the Russian Federation, the goals of sustainable development of rural areas are consistently fixed in the programs "Social development of the countryside until 2013" [4], "Sustainable development of rural areas for 2014-2017" [5]; "Comprehensive Development of Rural Areas, 20202025", the Strategy for Sustainable Development of Rural Areas of the Russian Federation for the period up to 2030 [6]. In the European Union, the sustainable rural development policy has been embodied in "The European Union's rural development policy" [7], as well as in various formats of the LEADER program. The 2030 Agenda, issued by the UN in 2015 [8], also highlights the mechanisms to be developed for ensuring sustainable rural growth at the international, national, regional and local levels. 
The variety of research approaches to the definition of sustainable development of rural areas is united by the thesis that, in the context of sustainability, socio-economic and spatial development should integrate, in the least conflict way, the key functions of rural areas in the system "man - environment". These are: agrarian-industrial, residential, recreational, health, aesthetic, biodiversity and cultural heritage conservation.

Bryant and Granjon [9] define sustainable development of rural areas as a process of continuous search for strategies aimed at an overall increase in the level of well-being and the formation of "healthy" rural communities, in which economic, socio-cultural, political and environmental values and imperatives are of equal importance, in the long run. At the same time, not seeing a significant difference between the problems of sustainability of rural and urban areas, these authors note some differences related to the type of environment, population density and conditions of economic activity, which can affect the risks of sustainable development, and proposed solutions for their levelling.

Paszkowski [10] emphasized that the practical implementation of the principles of sustainable development of rural areas requires consideration of the following parameters: territorial, multifunctional, dynamic and institutional.

The territorial component implies various options for the development of rural areas, due to spatial economic, social and environmental differentiation. Multifunctionality includes the need to analyse many factors of rural development (demographic, economic, social and environmental). Taking into account the transformations taking place in the economy- technology, social and cultural attitudes and the environment are the basis of the dynamic component; and the institutional component focuses on the social inclusion of various groups in the development and implementation of the concept of sustainable development and the coordination of activities through individual hierarchical levels of government.

The search for effective models for the development of rural areas, which, despite the diversity of institutional practices, as well as the consistent design of rural development in different countries, do not have sustainable socio-economic results, is an important research task. This task is inextricably linked with the assessment of sustainable development risks, since many of them are latent in nature. Objective information about risks is also required by state, corporate and individual investors, which suggests the possibility of comparative assessment of territories.

The purpose of the study is to develop methods for diagnosing risks to identify links between the current state of resources for sustainable development of rural areas and the tasks planned to be achieved.

\section{Materials and methods}

The research methodology is interdisciplinary. The main methodological construction is the spatial approach, which involves the study of the spatio-temporal dynamics of various phenomena of social and economic life. The paradigm of sustainable development and its new hybrid models (green and blue economy, low-carbon, circular economy) is used as a framework for identifying the main groups of risks for sustainable development of rural areas, taking into account the social, economic and environmental components. The developed methodology for assessing the risks of sustainable development of rural areas consists of constructing estimates of private risks using normalized values of the initial indicators and, on that basis, determining the consolidated risk. The territorial approach determined the possibility of identifying and differentiating various types of resources for the development of rural areas, as well as the risks of sustainable development. The comparative approach is used to identify and characterize various models of rural development within the framework of cross-local comparisons of socioeconomic and socio-culturally heterogeneous rural areas.

Empirical data (transcripts), obtained as a result of focus group discussions, an expert survey and traditional document analysis, were analysed and interpreted on the basis of a qualitative strategy using the method of polar comparisons to assess the dominant risks of sustainable development.

\section{Results and discussion}

The approaches to assessing the resources of rural areas, as well as analysing possible risks, are varied. Currently, there are two main approaches that can be used to diagnose the risks of sustainable development of rural areas. The first method is based on expert assessments and is used in cases of significant deficiency of correct information about the nature and degree of risk manifestation in a 
particular situation. The main disadvantages of this approach include: difficulties in the selection of experts, the possible subjectivity of assessments and the attendant difficulties with their verification.

The second method provides for the calculation of an integral aggregate indicator, including statistical quantitative indicators characterizing the particular risks of sustainable development. This method makes it possible to carry out a comparative analysis, in the context of territories, and is quite easy to understand from the point of view of content. At the same time, the methods used by various researchers can significantly differ from each other, both in the set of indicators for various types of private risks of sustainable development, and in the methods of aggregating the selected indicators. In addition, the persisting problem of the quality of statistics, the impossibility of reflecting many qualitative aspects of sustainable development using exclusively quantitative indicators, as well as the above-mentioned heterogeneity of rural areas, do not allow taking into account all the complexity and ambiguity of the context of the formation and development of various types of resources as sources of sustainable development of rural areas.

The actively occurring transformations, both in the nature of the rural economy and in terms of approaches used in relation to rural policy, make it necessary to carry out a typology of existing models of rural development, in order to identify typical development risks within each model and the possibility of further correct comparisons. It should be noted that most researchers note "one step" of the ongoing changes: from an approach focused mainly on the development of the agricultural sector to a more diversified economic activity [11; 12]. Marsden [13] explores three models of rural dynamics that define different degrees of sustainability: the agro-industrial model, the post-production model, and the emerging sustainable rural development model. Each of these models is dynamic and has a different level of real stability, which is determined by certain risks.

Our proposed research and typology algorithm includes the following stages:

Stage 1 - processing of basic indicators reflecting the dynamics of the state of rural areas. Basic indicators for various components of sustainable development are shown in Figure 1.

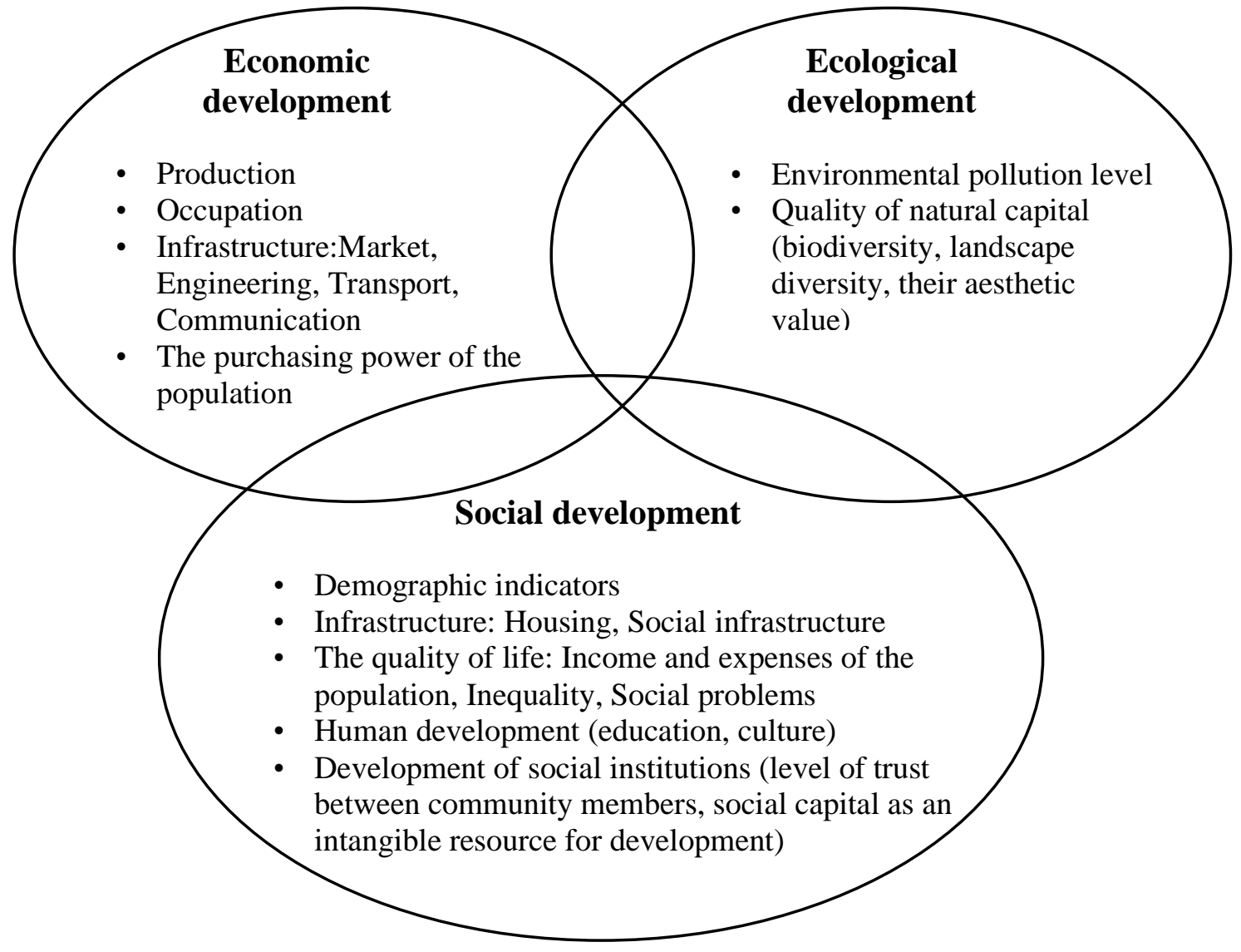

Fig. 1. Basic indicators for various components of sustainable development 
Stage 2 - identifying the types of rural areas. This stage provides the assessment and formation of private typologies of models for the development of rural areas, depending on the available development resources and key characteristics. Empirical research demonstrates a significant number of resources that can ensure the successful implementation of the concept of sustainable rural development. The systematic approach makes it possible to consider, in parallel, the relationship between various resources for sustainable development of rural areas, the tasks planned to be achieved and the possible risks of their solution.

Stage 3 - an integral grouping of the selected types and formation of generalizing characteristics, taking into account risk-forming factors. So, for example, individual models of the development of rural areas, determined by their resources and the main risk-forming factors, presented in Table 1:

Table 1

\section{Typology of rural development models}

\begin{tabular}{|c|c|c|c|}
\hline $\begin{array}{c}\text { Development } \\
\text { model }\end{array}$ & Characteristic & $\begin{array}{l}\text { Development } \\
\text { resources }\end{array}$ & Main risk factors \\
\hline $\begin{array}{l}\text { Mono sectoral } \\
\text { agricultural } \\
\text { model }\end{array}$ & $\begin{array}{l}\text { Old-developed } \\
\text { agricultural areas with a } \\
\text { predominant type of crop } \\
\text { or livestock production } \\
\text { by large corporate } \\
\text { enterprises. The real } \\
\text { potential for economic } \\
\text { and social development } \\
\text { is significantly limited }\end{array}$ & $\begin{array}{l}\text { Intensification and } \\
\text { concentration of } \\
\text { agricultural production } \\
\text { by agro-industrial type }\end{array}$ & $\begin{array}{l}\text { - Loss of biodiversity } \\
\text { - Natural resource deficiencies } \\
\text { - Instability of single-industry } \\
\text { specialization to external shocks, } \\
\text { monopoly position of a large } \\
\text { employer }\end{array}$ \\
\hline $\begin{array}{l}\text { Diversified } \\
\text { model }\end{array}$ & $\begin{array}{l}\text { Territories with } \\
\text { developed vertical or } \\
\text { horizontal diversification } \\
\text { of rural economy sectors }\end{array}$ & $\begin{array}{l}\text { Maximum full use of } \\
\text { territorial potential, } \\
\text { multiplier effects of } \\
\text { new types of economic } \\
\text { activity }\end{array}$ & $\begin{array}{l}\text { - Multidirectional negative impact } \\
\text { on the environment } \\
\text { - Negative externalities between } \\
\text { different branches of agricultural } \\
\text { production } \\
\text { - The emergence of new "growth } \\
\text { points" causes a general rise in } \\
\text { the cost of living, which is not } \\
\text { compensated for in other } \\
\text { industries }\end{array}$ \\
\hline $\begin{array}{l}\text { Urbanised } \\
\text { model }\end{array}$ & $\begin{array}{l}\text { Territorial expansion of } \\
\text { the boundaries of urban } \\
\text { agglomerations at the } \\
\text { expense of the nearest } \\
\text { suburban spaces and the } \\
\text { spread of urban forms of } \\
\text { life in rural areas. }\end{array}$ & $\begin{array}{l}\text { The factor of seasonal } \\
\text { suburbanization: a } \\
\text { wide demand for } \\
\text { seasonal housing } \\
\text { stimulates the active } \\
\text { development of the } \\
\text { recreational and } \\
\text { residential function, the } \\
\text { penetration of "urban" } \\
\text { functions, the presence } \\
\text { in the immediate } \\
\text { vicinity of a large } \\
\text { urban sales market and } \\
\text { cheaper than urban } \\
\text { resources (land, real } \\
\text { estate) }\end{array}$ & $\begin{array}{l}\text { - Infrastructure constraints: } \\
\text { seasonal influx of population } \\
\text { reduces the volume and quality of } \\
\text { services provided and creates } \\
\text { additional conflicts } \\
\text { - Loss of territorial identity } \\
\text { - Weak ability to use local } \\
\text { specifics and local resources to } \\
\text { trigger development processes }\end{array}$ \\
\hline $\begin{array}{l}\text { Local eco- } \\
\text { oriented } \\
\text { model }\end{array}$ & $\begin{array}{l}\text { Ecotourism development } \\
\text { areas and areas with } \\
\text { special environmental } \\
\text { restrictions }\end{array}$ & $\begin{array}{l}\text { Natural capital of the } \\
\text { territory, social capital } \\
\text { of the local community }\end{array}$ & $\begin{array}{l}\text { Deterioration of the habitat due to } \\
\text { the overexploitation of natural } \\
\text { systems, established traditions and } \\
\text { stereotypes that inhibit } \\
\text { development }\end{array}$ \\
\hline
\end{tabular}

Modern approaches to assessing risks at the territorial level in most cases are based on the calculation of the integral indicator. Differences when using this approach in most cases are associated 
with differences in the identification of various types of private investment risks, the choice of indicators involved in the assessment, as well as the methods of aggregating the selected indicators.

We propose a methodology for assessing the risks of sustainable development of rural areas, based on the construction of estimates of the private risks of sustainable development of each territory using normalized values of the initial indicators and determining on their basis the cumulative risk. The technique consists of the following stages:

- identification of development risks for each type of rural area;

- preparation of an information base for risk assessment;

- assessment and analysis of the values of private risks of development of territories;

- assessment and analysis of the consolidated risk values;

- formulation of conclusions and recommendations.

At the first stage of the implementation of the methodology, the key risks of the development of rural areas, characteristic for each type of rural area, the sources and factors of their occurrence are determined.

At the second stage, the task of preparing an initial information base for risk assessment is solved, which includes quantitative and qualitative indicators (for example, statistical indicators characterizing private risks or expert scores) criteria:

- representativeness, according to which the selected indicators characterize the considered category most fully;

- availability, according to which indicators are subject to registration by state statistics bodies, sectoral departments or are calculated on their basis.

The proposed methodological approach includes, along with the methods of collecting quantitative data traditional for economic research, specific research methods: sociological (expert methods), as well as statistical and mathematical methods that make it possible to "work" with large amounts of empirical data. Expert assessments include two projections: the current state of sustainability of the rural area (positive analysis) and the target, reference state (normative analysis) and are ranked according to three intervals of a 100-point scale. The reliability of the consistency of expert assessments is checked by the method of canonical and positional analysis. In order to neutralize the possible subjectivity in expert assessments, the original authors' computer program (Visual Basic 2015) can be used, which allows assessing the contribution of each expert to the consistency of the opinion of the expert community using the Cronbach alpha criterion, the calculation of which is based on determining the variances of expert assessments of objects and the variance of their amounts [14].

The scores are formed by assigning a group of experts to each analysed territory points from 0 to 100 , where 0 corresponds to the lowest risk level, and 100 corresponds to the most unfavourable conditions.

The third stage is a quantitative assessment of the private risks of territorial development. The values of the initial indicators that have a positive effect on the level of private risk are subject to the standardization procedure according to the following formula (1):

$$
y_{i j}=\frac{x_{i j}-x_{j}^{\min }}{x_{j}^{\max }-x_{j}^{\min }}
$$

and for indicators that have a negative impact according to the formula (2):

$$
y_{i j}=\frac{x_{j}^{\max }-x_{i j}}{x_{j}^{\max }-x_{j}^{\min }}
$$

where $y_{i j}$ - normalized value of the indicator;

$x_{i j}$ - actual value of the indicator;

$x_{j}^{\text {max }}$ - maximum value of the indicator;

$x_{j}^{\text {min }}$ - minimum value of the indicator;

$i$ - number of the territory for which the assessment is being carried out, $i=1,2, \ldots n$;

$j$-number of the indicator that participates in the assessment, $j=1,2, \ldots m$. 
It is proposed to calculate a quantitative assessment of private risks of sustainable development of territories using the arithmetic mean formula (3):

$$
r_{i k}=\sum_{j=1}^{m^{(k)}} \frac{y_{i j}}{m^{(k)}}
$$

where $\quad r_{i k}$-assessment of the private risk $k$ for $i$ territory, $k=1,2, \ldots l$;

$m^{(k)}$ - subset of the initial indicators involved in the assessment of the private risk $k$.

To assess the consolidated risk of sustainable development of the territory, it is proposed to use the arithmetic weighted average formula (4):

$$
R_{i}=\frac{\sum_{k=1}^{l} r_{i k} * \omega_{k}}{\sum_{k=1}^{l} \omega_{k}}
$$

where $R_{i}$ - the total risk of investing in $i$ territory,

$\omega_{k}$ - weight coefficients of the significance of private risks.

The values of the weight of each coefficient are determined by the expert method for each type of territory.

All quantitative assessments take values from 0 to 1 . To determine the degree of manifestation of risks for each territory, the following scale is introduced, based on the values of the quantitative assessment of private and consolidated risks:

- minimum risk at values from 0 to 0.25 inclusive;

- permissible risk at values from 0.25 to 0.5 inclusive;

- high risk at values from 0.5 to 0.75 inclusive;

- critical risk at values over 0.75 .

At the final stage, the analysis and comparison of the level of risks in the context of each type of territories are carried out, the corresponding conclusions and recommendations are formulated.

\section{Conclusions}

1. The discourse of sustainable development of rural areas, actively articulated in political, scientific and social contexts, forms a research field in the search for the most effective models of rural development and sets the task of developing methods for diagnosing risks to identify links between the current state of resources for sustainable development of rural areas and planned achievement of goals.

2. The approach proposed in this article takes into account the significant heterogeneity of rural areas in terms of development resources, various types of transformation of rural areas under the influence of external and internal factors, as well as existing and potential risks. The typology algorithm includes a preliminary assessment of basic indicators reflecting the dynamics of the state of rural areas in terms of economic, social and environmental components, assessment and formation of private typologies of rural development models depending on the available development resources and key characteristics, and their subsequent classification, taking into account risk-forming factors. The authors singled out a single-industry agricultural, diversified, urbanized and local eco-oriented model.

3. The developed methodology for assessing the risks of sustainable development of rural areas is based on the construction of assessments of the private risks of sustainable development of each type of rural area, using normalized values of the initial indicators and on the basis of determining the overall risk. The methodology includes both traditional methods of collecting and analysing quantitative data, as well as expert methods, and statistical and mathematical methods that make it possible to "work" with large amounts of empirical data. At the same time, to level the possible subjectivity in expert assessments, it is proposed to use the original authors' computer program (Visual Basic 2015), which makes it possible to assess the contribution of each expert to the consistency of the opinion of the expert community using the Cronbach alpha criterion, the calculation of which is based on determining the variances of expert assessments of objects and the variance of their sum. 
4. The methodology consists of five sequential stages, allowing to identify the key risks of development of each type of rural area, create an information base for diagnosing risks, analyse the values of private risks of development of territories, determine on this basis the values of the consolidated risk, and formulate conclusions and recommendations that may be in demand state, corporate and individual investors, as well as other subjects of rural development.

\section{References}

[1] Троцковский А.Я., Мищенко И.В., Мищенко О.А. Пространственное развитие сельской периферии: методология и основные результаты исследования (Spatial development of rural periphery: methodology and main research results) // Региональная экономика: теория и практика. 2014. No. 45. (In Russian). [online] [20.03.2021]. Available at: https://cyberleninka.ru/article/n/prostranstvennoe-razvitie-selskoy-periferii-metodologiya-iosnovnye-rezultaty-issledovaniya.

[2] Меренкова И.Н. Устойчивое развитие сельских территорий: теоретико-методологические аспекты оценки (Sustainable Development of Rural Areas: Theoretical and Methodological Aspects of Assessment) // Региональная экономика: теория и практика. 2010. No. 25. (In Russian). [online] [16.03.2021]. Available at: https://cyberleninka.ru/article/n/ustoychivoerazvitie-selskih-territoriy-teoretiko-metodologicheskie-aspekty-otsenki

[3] Леметти Ю.А. Базовые проблемы перехода сельского хозяйства России на путь устойчивого развития (Basic problems of the transition of Russian agriculture to the path of sustainable development) // Экономические исследования. 2011. No. 4. (In Russian).

[4] Федеральная целевая программа “Социальное развитие села до 2013 года” (Social development of the countryside until 2013). (In Russian). [online] [12.03.2021]. Available at: https://fcp.economy.gov.ru/cgi-bin/cis/fcp.cgi/Fcp/ViewFcp/View/2013/151/

[5] Федеральная целевая программа "Устойчивое развитие сельских территорий на 2014 - 2017 годы и на период до 2020 года" (Sustainable development of rural areas for 2014-2017). (In Russian). [online] [12.03.2021] Available at:

http://www.consultant.ru/document/cons_doc_LAW_149879/f6d8bd0f68f7f8116ff6801b36604b3 $380 \mathrm{bc} 295 \mathrm{e} /$

[6] Стратегия устойчивого развития сельских территорий Российской Федерации на период до 2030 года (The Strategy for Sustainable Development of Rural Areas of the Russian Federation for the period up to 2030) (In Russian). [online] [26.03.2021] http://government.ru/docs/16757/

[7] The European Union's rural development policy. [online] [12.03.2021] Available at: https://ec.europa.eu/info/food-farming-fisheries/key-policies/common-agricultural-policy/ruraldevelopment

[8] Transforming our world: the 2030 Agenda for Sustainable Development. [online] [12.03.2021] Available at: https://sdgs.un.org/2030agenda

[9] Bryant C., Granjon D. Rural sustainability. In Human Settlement Development, Encyclopedia of Life Support Systems; EOLSS Publisher: Montreal, QC, Canada, Vol. 2, 2009, pp. 158-167.

[10] Paszkowski S. Sustainable development of agriculture and rural areas, in: The economy, man and environment in rural areas, Klodzinski M. (ed.), IRWIR PAN, Warsaw. 2000.

[11] Leon Y. Rural development in Europe: a research frontier for agricultural economists. European Review of Agricultural Economics, vol. 32, iss. 3, 2005, 301-317.

[12] Van der Ploeg J., Renting H., Brunori G., Knickel K., Mannion J., Marsden T., de Roest K., SevillaGuzmán E., Ventura, F. Rural development: from practices and policies towards theories. Sociologia Ruralis, vol. 40, iss. 4, 2000, pp. 391-408.

[13] Marsden T. The Conditions of Rural Sustainability; Royal van Gorcum: Assen, The Netherlands. 2003.

[14] Терешина М.В., Мирошниченко И.В., Акиньшина В.А., Халафян А.А. Программа ЭВМ «Оценка согласованности экспертных оценок в диагностике институциональной устойчивости региональной инновационной системы позиционным анализом» (Computer program "Assessment of the consistency of expert assessments in the diagnosis of institutional stability of the regional innovation system by positional analysis"). (In Russian). [online] [20.03.2021] Available at: https://www.elibrary.ru/item.asp?id = 42497351 